\title{
JOURNA OF PHILOSOPHICAL STUDIES
}

adduces the Van der Waals' equation, which "was devised to represent the behaviour of substances in a state of vapour, but was then found to express the change from the gaseous to the liquid state." And he suggests further developments in terms of "stable oscillations about the points of a space-lattice" which "would express the passage from liquid to crystal."

This is admirably to the point. I hope that it may open up further discussion. But would a contribution to such further discussion on my part be of any value? It is surely a matter for experts well up to date in physics and in the logic of the deducible.

There I might leave it. Lest, however, this should seem discourteous to your correspondent, or be taken as canny evasion of a pertinent issue, I will add just a little.

The question, as I read it, is whether in passing from vapour to liquid, and from liquid to solid, in this or in reversed order, all that happens is deducible, or something that happens escapes the close meshwork of deduction. It is for the expert to say. He can tell us the rules of the game expressed in suitable equations. No doubt there are rules common to all three games. Does this imply that there are no rules distinctive of each of them? If it be said that there is nothing emergently distinctive, what does this mean? It means, I think, that given all the rules of any one game, all the rules of the other two games (as they are actually played in existent nature) are simply matters of logical deduction on the part of one who is suitably trained for this task.

Let us then suppose that in some corner of the universe the order of evolution was first vapour, then liquid, then solid. Let us also suppose that some imaginary person, adequately trained, lived in the precedent vapour-epoch and knew all the rules of this game. Then he could foretell all the rules of the liquid-game, and all the rules of the solid-game, though neither of these subsequent games were yet in play in his corner of the universe. They would be the actual rules in the existent world, not only such rules as were logically possible.

I do not say that he could not do so. I only ask: Could he do so? It is for the expert to tell us whether, in this province of inquiry, there are what Mr. Broad calls "trans-ordinal laws" or not.

With brief reference to the life-game, Mr. Chapman reminds us that Professor Boycott finds it "hard to say where the term 'living' becomes appropriate and where it ceases to be so." Many others are in like case. Experts along different lines of inquiry seek an answer to the question: Of what nature were the evolutionary precursors of unicellular organisms? Who can say, since we do not know the world-conditions under which these precursors in some way came into being? We can only conduct investigations under the conditions which are found, or which may be imposed, here and now. Along one line of approach here and now we are faced with the "virus-problem." It is highly technical-essentially a problem in which only expert opinion carries much weight. The present position, so far as an interested outside can gather, is in brief this: Some "filter-passers" are living: some may be not-living. Along this line of inquiry one does not seem yet to be within sight of an answer to the question: Are all the rules of the living-game deducible from those of the not-living game? In other words, "Emergent or notemergent?" remains an open question.

Yours faithfully,

C. Lloyd Morgan.

ST. LeONARDS-ON-SeA.

TO THE EDITOR OF THE Journal of Philosophical Studies.

\section{OPERA HACTENUS INEDITA ROGERI BACONI.}

SiR,

I find it a little difficult to characterize adequately the temerity of Professor A. E. Taylor's excursions into intuitive palæography. Anyone who thinks that the contraction for cum is $\mathrm{cm}$ and for tamen is $\mathrm{tm}$ is surely debarred from writing on the matter at all. Whatever $\mathrm{cm}$ may stand for-and palæography is full of snags- 


\title{
C ORR ES P O N E N CE
}

one thing it never means is cum; and though $\mathrm{tm}$ stood for tamen up to the ninth century, after the change of hand it is restricted to tantum. No wonder he finds a long list of errors in Fr. Delorme's text. It is perhaps a little unusual for one who has never edited a mediæval text from the manuscripts to put on paper a suggestion that a scholar who has devoted his whole life to the publication of thirteenth and fourteenth century texts-many of them for the first time-cannot read a manuscript, and to say what that manuscript, which the critic has never seen, contains. Professor Taylor's suggestions of its content have no foundation. I13.34 'esse divini' is written in full. 249.16 'superiora' is in the manuscript.

Since this is not the first time that Professor Taylor has commented, equally rashly, on the text of these fascicules, may I be allowed to inform him that "edidit" is not the Latin for "critically edited," for which there is a well-known formula. The object of this publication, as has been repeatedly said, is to let students know what is in the manuscript, and this has been done in every case. Fr. Delorme and I, with the kind assistance of some distinguished scholars, have spared no pains to this end, and we welcome any criticism which will help to elucidate the thought of Bacon. We do not and cannot object to any criticism of our editorial methods.

ROBERT Strele.

\section{Savagr Club,} W.C.

To THE EDITOR OF THE Journal of Philosophical Studies.

\section{PROFESSOR TAYLOR'S REPLY.}

SIR,

I have already acknowledged my mistake about the origin of the readings esse divini and superiora, and expressed my regret for it. That the words are corruptthough superiora may be a corruption of superiorum, not as I suggested of signorum-I am prepared to show when anyone will defend them. For the rest, Mr. Steele himself makes no reply to my remarks about confusions of materia with natura, and the omission of necessary negatives. As to his charge of ignorance, it is partly based on an oversight. The abbreviation of tamen which I had in mind was $t n$. There remains the complaint that I had thought cum might in a certain place be written $\mathrm{cm}$. I made this remark in the belief that I had recently seen the word written so in a careful transcript of a MS. apparently of rather later date than the Amiens MS. of Bacon's Questiones. It is only too possible that my memory was in fault; but whether the fault calls for the hard words Mr. Steele uses I must leave it to others to judge.

Yours faithfully,

A. E. TAYLOR,

EDINBURGh,

June 5, 1929.

\section{OBITUARY NOTICE}

\begin{abstract}
At the moment of going to Press, the sad news has reached us of the sudden death of the distinguished and beloved Chairman of the Institute, Professor Leonard Trelawney Hobhouse. An account of his life and work will appear in a subsequent issue.
\end{abstract}

